\title{
High Temperature High Pressure Thermodynamic Measurements for Coal Model Compounds
}

\author{
Semi-Annual Report \\ September 1, 1996 - February 28, 1997 \\ By: \\ Vinayak N. Karadi \\ John C. Chen
}

Work Performed Under Contract No.: DE-FG22-95PC95214

For

U.S. Department of Energy

Office of Fossil Energy

Federal Energy Technology Center

P.O. Box 880

Morgantown, West Virginia 26507-0880

By

North Carolina A\&T State University

Chemical Engineering Department

Mechanical Engineering Department

Greensboro, North Carolina 27411 


\section{Disclaimer}

This report was prepared as an account of work sponsored by an agency of the United States Government. Neither the United States Government nor any agency thereof, nor any of their employees, makes any warranty, express or implied, or assumes any legal liability or responsibility for the accuracy, completeness, or usefulness of any information, apparatus, product, or process disclosed, or represents that its use would not infringe privately owed rights. Reference herein to any specific commercial product, process, or service by trade name, trademark, manufacturer, or otherwise does not necessarily constitute or imply its endorsement, recommendation, or favoring by the United States Government or any agency thereof. The views and opinions of authors expressed herein do not necessarily state or reflect those of the United States Government or any agency thereof. 


\section{DISCLAIMER}

Portions of this document may be illegible in electronic image products. Images are produced from the best available original document. 


\section{PROJECT OBJECTIVES AND SCOPE}

The overall objective of this project is to develop a better thermodynamic model for predicting properties of high-boiling coal derived liquids, especially the phase equilibria of different fractions at elevated temperatures and pressures. The development of such a model requires data on vapor-liquid equilibria (VLE), enthalpy, and heat capacity which would be experimentally determined for binary systems of coal model compounds and compiled into a database. The data. will be used to refine existing models such as UNIQUAC and UNIFAC.

\section{TECHNICAL HIGHLIGHTS AND MILESTONES}

The flow VLE apparatus designed and built for a previous project was upgraded and recalibrated for data measurements for this project. The modifications include better and more accurate sampling technique and addition of a digital recorder to monitor temperature, pressure and liquid level inside the VLE cell. VLE data measurements for system benzene-ethylbenzene have been completed. The vapor and liquid samples were analysed using the Perkin-Elmer Autosystem gas chromatograph. A capillary column made by Supelco, and the FID detector were used for the analysis. P,T,X,Y data were measured along the isotherms $180 \mathrm{C}, 210 \mathrm{C}, 250 \mathrm{C}, 280 \mathrm{C}$, and $300 \mathrm{C}$. The smoothed data were found to be fairly well behaved when subjected to thermodynamic consistency tests.

SETARAM C-80 calorimeter was used for excess enthalpy measurements for benzeneethylbenzene liquid mixtures. The goal is to measure data from $30 \mathrm{C}$ to $285 \mathrm{C}$ for liquid mixtures covering the entire composition range. A number of problems were encountered during the enthalpy measurements. The most serious ones were the entrapment of air in the sample cell and degasing of the sample at high temperatures. Design modifications were necessary to eliminate or at least reduce their effect on the measured data. As a result, very accurate data could be measured at lower temperatures $(<200 \mathrm{C})$, but the uncertainty in the measured values increased at higher temperatures. The data measurements are continuing.

The combined VLE and liquid enthalpy data will be used to regress temperature dependent binary interaction parameters in the Wilson, NRTL and UNIQUAC activity coefficient models, and the temperature dependent binary group interaction parameters for the aromatic $\mathrm{CH}$ and alkyl $\mathrm{CH} 2$ groups in the UNIFAC model. Computer programs to do this have been developed.

Most of the work completed so far was done by the graduate student Mr. Ahmad AlGhamdi, who finished his M.S. thesis in March, 1997. The experimental measurements are being continued by the M.S. graduate student Mr. Qingwen Zhao. In what follows, the VLE and the enthalpy measurements are discussed in more details. 


\section{VAPOR-LIOUID EOUILIBRIUM (VLE) MEASUREMENTS}

\section{THE APPARATUS:}

From a previous project funded by Department of Energy we built an apparatus to measure VLE data for both known mixtures of aromatic compounds and heavy polynuclear coal liquids. The apparatus is shown in Figure 1 with the cross section of the equilibriam cell shown in Figure 2. The same apparatus will be used for the VLE measurements necessary for this project.

The apparatus can be divided into four sections, feed section, equilibration section, sampling section, and lastly the control-panel section. The maximum designed temperature and pressures for this system are $500^{\circ} \mathrm{C}$ and $2000 \mathrm{psi}$, respectively. All parts and tubing, including the ones exposed to the high temperature zones, are made of stainless steel (type 316). The tubing used in the fabrication is mostly of $1 / 4$ inch diameter and at some places of $3 / 8$ inch diameter. The fittings used are swagelok compression type, made of the same material SS-316.

This VLE apparatus consists of the equipment/components namely, feed tank, positive displacement metering pump, pre-heater oven, main heater oven, vapor-liquid equilibrium cell with a circular coil of tubing around it in which the liquid gets heated before entering the cell, two heat-exchangers, two control valves, one safety valve, one pulsation dampening bottle, eighteen plug valves (most of the fittings are of $1 / 4$ " diameter), and two strainers.

The purpose of designing and fabrication of this type of apparatus is to provide a steady supply of test liquid mixture, into the vapor-liquid equilibrium cell, at a very small flow rate and under controlled pressure. The liquid is heated, gradually to the equilibrium temperature in two ovens, before it is introduced into the VLE cell to achieve the equilibrium between the liquid and the vapors. Once we have reached this stage, vapor and the liquid will continuously be separated and sent to their respective coolers, through the respective openings out of the VLE cell. The vapors and the liquid streams are cooled and sent to the sample bottles through metering valves, for the collection of the samples. The amount of the sample taken can be controlled by opening of the metering (needle) valves for the desired time period. The excess amount of vapor and liquid streams are sent back to the main feed tank.

The main advantage of this type of flowapparatus is that a steady state continuous system is established, as the amount of vapor and liquid being taken out of the system at equilibrium is 
continuously compensated by the fresh liquid-mixture stream coming in at the equilibrium temperature. After start-up, the system takes about an hour to come to desired temperature and pressure and it takes another two hours for the liquid and vapor in the VLE cell to equilibrate. These times although long are considerably shorter than equivalent equilibration times for a static equilibrium cell.

The control panel consists of the pre-heater controller, the main heater controller, two controllers for the pressure and level control loops, a thermocouple key, a temperature digital display and two pressure gauges. The original apparatus used a three pen chart recorder to record the pressure, liquid level and the temperature in the VLE cell. This has been replaced by a multisignal digital chart recorder that allows saving of the signals on memory cards for further data analysis. All these components of the apparatus are very carefully placed on a frame, built from channels, fittings and wood panels.

The equilibrium cell is a cylindrical vessel made of stainless steel 316 with 1" thick walls (Figure 2). The cap of the cell is threaded and screws into the main body. Various ports are provided in the cell body for feed inlet, liquid and vapor outlet, pressure line and insertion of the thermocouple probe. A large port is provided at the top of the cell for mounting of the liquid level sensor. This sensor is welded to a flange which is bolted to the top of the cap. Stainless steel and inconel vented ' $O$ ' rings are used as seals for the cell cap as well as the flange carrying the liquid level sensor.

To achieve equilibrium in the VLE cell, temperature, pressure and liquid level in the cell need to be controlled as closely as possible. The temperature is controlled by the Honeywell UDC5000 temperature controller provided with the main oven. Two feedback control loops are used to control liquid level and the pressure in the cell. The liquid level is sensed by an electrical conductivity probe and controlled by manipulating a control valve on the liquid outlet line. The pressure in the cell is sensed by a Rosemont pressure transmitter and controlled by manipulating a control valve on the vapor outlet line. Once the cell contents reach conditions close to the desired values, the control loops are successful in maintaining them at the required values with minimal fluctuations.

The VLE apparatus uses an opaque stainless steel cell unlike the see-through glass window cells used in various other studies in the literature. As a result, reliable level sensing is very crucial in our measurements. The electrical conductivity probe used in our apparatus was pur- 
chased from Delta $\mathrm{M}$ corporation who modified their existing LC-2300 conductivity probe to operate at higher temperatures $\left(<500^{\circ} \mathrm{C}\right)$ and higher pressures $(<1500 \mathrm{psi})$ according to our specifications. The Delta M LC2000 series of instruments employ thermal based sensors. Power is supplied to the sensors, and the returning sensor signal is converted to a standard 4-20 mA signal by solid state electronics.

The sensing element in the 262000 Series level probes is a wire with a linear resistance versus temperature coefficient $R(T)$. The temperature, and therefore the resistance, of this wire at any point along its length is determined by the amount of heater power to the probe and the thermal heat transfer from the probe surface to the surrounding media. The heat transfer properties (thermal conductivity and diffusivity), of the liquid whose level is to be measured is generally significantly greater (as much as 100 times) than the air or vapor phase above it. Therefore an increment of resistance (delta $\mathrm{R}$ ) in the sensor wire is directly proportional to the length not submerged in the liquid. With many level sensing techniques, a change in the process temperature will alter the operation of the device, yielding false readings. The Microtuf LC2000 Series design includes a compensation feature which avoids this problem. The heated sensor has a temperature profile which is the sum of the temperature of the media with which it is in contact plus an incremental temperature determined by the amount of self heating and the thermal properties of the two media. The second (unheated) sensor, located adjacent to and parallel with the heated sensor, has a temperature profile which exactly matches the media temperature near the heated sensor. The unheated sensor signal is electronically subtracted from that of the heated sensor, leaving only the thermal based level signal which is now relatively independent of the temperature of the media. For the previous DOE project calibration curves were prepared for the level probe at various temperatures ranging from $50 \mathrm{C}$ to $400 \mathrm{C}$. The probe signal was found to be pressure independent. These calibration curves will be used in the current measurements.

\section{PROCEDURE:}

A schematic flow diagram of the flow-type apparatus designed and made for this work is shown in figure 1 (numbers in brackets in what follows correspond to legend numbers of Figure 1). Feed from the feed tank (13) is filtered through two strainers ( $22 \& 25$ ) of 60 and 230 microns respectively and is pumped, by a positive displacement metering pump (1), to the pre-heater oven (2). The liquid stream is heated while it passes through a coil shaped tubing in the pre-heater (2). The coiled tubing provides the maximum surface area for the heat transfer to the liquid flowing 
through it. Here the temperature of the liquid is raised to within $10-20{ }^{\circ} \mathrm{C}$ of the temperature desired in the main heater oven (3). The feed then enters the second coil placed inside the main heater where the temperature of the liquid stream is again raised so as to bring it close enough, i.e., $\pm 1{ }^{\circ} \mathrm{C}$ to the desired temperature within the vapor-liquid equilibrium cell (15). The vapor and liquid flow rates out of the VLE cell are controlled by two control valves (4), placed on the respective lines. Manipulation of the output of these valves to increase or decrease the flow rates of the vapors and liquid from the cell, help to control the pressure and the liquid level to desired values. The vapor and liquid from the cell are carried by two separate lines to the two respective double pipe heat exchangers (9), where they are cooled down to $35-50{ }^{\circ} \mathrm{C}$. A sampling point is provided on each line $(11,12)$. Streams from the two heat exchangers are then combined and sent back to the feed tank. A third sample point $(10)$ is provided on the feed line. The samples of the feed, vapor, and the liquid streams can be taken once the equilibrium conditions have been established. The quantity of the samples to be taken, can be easily controlled with the help of the metering valves (23) (needle valve), placed in the sample extension lines. Once the samples are collected, they are tested and analyzed by chromatographic methods.

Both the pre-heater and the main oven are provided with independent controllers, which control the set points in the range of $\pm 1{ }^{\circ} \mathrm{C}$ temperature difference. The main heater controller works on the weighted average of the two inputs, one from the interior of the oven and the other from the inside of the vapor-liquid equilibrium cell. Both of these along with the other thermocouples, placed at various locations, are of J type Iron/Constantan. These thermocouples were calibrated against two reference points of water, i.e., freezing and boiling points.

The pressure and liquid levels are controlled by two feedback control loops. The pressure of the VLE cell is measured by the Rosemont pressure transmitter, which sends a 4-20 mA signal to the controller which then manipulates the flow rate of the vapor out of the VLE cell through a control valve placed in the vapor line.

The liquid level inside the VLE cell is measured by the Delta-M LC2300 level sensor. The probe, after sensing the level, sends the signal to the controller which in turn manipulates the control valve on the liquid outlet line in order to keep the level constant. 


\section{METHOD OF ANALYSIS:}

The analysis of the samples (benzene, ethylbenzene mixtures) obtained from the VaporLiquid apparatus are carried out by the gas chromatographic method. The method specifically designed for the benzene-ethylbenzene binary system is given below:

$\begin{array}{ll}\text { Instrument: } & \text { Perkin-Elmer AutoSystem gas chromatograph } \\ \text { Injector: } & \text { Programmed split-splitless (PSS), with narrow glass liner } \\ \text { Column: } & \text { Supelco Beta-Dex 110, Fused silica capillary column, 30m, } \\ & 0.25 \mathrm{~mm} \text { ID } \\ \text { Detector: } & \text { Flame Ionization detector (FID) } \\ \text { Carrier Gas: } & \text { Helium (inlet pressure 15psi) } \\ \text { Injection size: } & 0.1 \text { microliter } \\ \text { Dilution solvent: } & \text { Methanol } \\ \text { Injector temperature: } & 200 \mathrm{C} \\ \text { Column temperature: } & 50 \mathrm{C} \\ \text { Detector temperature: } & 260 \mathrm{C} \\ \text { Data analysis: } & \text { Waters Maxima chromatographic software }\end{array}$

The standard used for calibration was a solution of equal volumes of benzene and ethylbenzene. The solution was diluted by methanol solvent so that 0.1 microliter of the solution would contain approximately 100 nanograms of each of benzene and ethylbenzene, a limit as recommended by Supelco, the distributor of the GC column. The chromatogram for the standard and the data analysis are given in the appendix. Assuming a linear relation between the response and concentration, the concentration of brnzene in an unknown solution would then be given by

Vol \% benzene in unknown $=\mathrm{R}_{\mathrm{B}} /\left(\mathrm{R}_{\mathrm{B}}+\mathrm{k} * \mathrm{R}_{\mathrm{EB}}\right)$

where $R_{B}$ and $R_{E B}$ are responses of benzene and ethylbenzene in the unknown sample in microvolts-sec, and $\mathrm{k}$ is the ratio of the response factor of ethylbenzene to that of benzene corresponding to the standard solution (see the appendix). After a few calibration runs, the following values of $\mathrm{k}$ were determined for two different concentration ranges: 1.135 for mixtures with vol $\%$ benzene greater than $50 \%$, and 1.168 for mixtures with vol $\%$ benzene less than $50 \%$. 


\section{EXPERIMENTAL DATA:}

Experimental VLE data were measured for the benzene (1) - ethylbenzene (2) system along four isotherms, $180 \mathrm{C}, 210 \mathrm{C}, 250 \mathrm{C}$, and $280 \mathrm{C}$. Temperature, pressure, mole fraction of benzene in liquid $\left(\mathrm{X}_{1}\right)$ and mole fraction of benzene in vapor $\left(\mathrm{Y}_{1}\right)$ are given in Table 1 . The $\mathrm{X}-\mathrm{Y}$ diagrams are plotted in Figure 3 and $\mathrm{P}-\mathrm{X}-\mathrm{Y}$ diagrams are shown in Figure 4.

\section{DATA ANALYSIS:}

The VLE data were analyzed for consistency by first calculating activity coefficients, and then applying the Gibbs-Duhem equation in the form of the area test expained below. The activity coefficients were calculated using the following equation

$$
\gamma_{i}=\left(y_{i} P \phi_{i}\right) /\left(x_{i} P^{\text {sat }} \phi_{i}^{\text {sat }} \text { Poynt }\right)
$$

where,

$\gamma_{\mathrm{i}}$ is the activity coefficient

$P$ is the total pressure

$\phi_{i}$ and $\phi_{i}^{\text {sat }}$ are the fugacity coefficients of component $i$ in the vapor phase, and the fugacity coefficient of pure vapor of component $i$ at equilibrium with liquid at $T$ and $P^{\text {sat }}$

$\mathrm{P}^{\mathrm{sat}}$ is the vapor pressure of pure liquid $\mathrm{i}$ at $\mathrm{T}$

Poynt is the Poynting correction factor for pure liquid i at $\mathrm{T}$ and between pressures $\mathrm{P}^{\text {sat }}$ and P.

We used the Peng-Robinson equation of state for the vapor phase, Wagner equation for the vapor pressures and Rackett equation for liquid molar volumes. The various quantities calculated are tabulated in Table 2. The area test for thermodynamic consistency involves satisfaction of the following equation:

$$
\int_{0}^{1} \ln \left(\gamma_{2} / \gamma_{1}\right) d x_{1}=0
$$


In Figure $5, \ln \left(\gamma_{2} / \gamma_{1}\right)$ is plotted versus $x_{1}$, and it is observed that all four curves go through zero at around $x_{1}$ equal to 0.5 . Also the areas under the curves were computed numerically, and in all cases they were close to zero. The data is therefore thermodynamically consistent. We have plans to use this data set to regress parameters in various activity coefficient models, and this will be especially useful when our excess enthalpy data set for this system is ready. Work is going on in that direction. 
Table 1

Experimental VLE Data for Benzene (1) - Ethylbenzene (2) System

\begin{tabular}{|c|c|c|c|}
\hline$\underline{T(C)}$ & $\underline{\mathrm{P}} \underline{\text { (bar) }}$ & $\underline{X}_{1}$ & $\underline{Y}_{1}$ \\
\hline \multirow[t]{7}{*}{180} & 3.452 & 0.0778 & 0.2200 \\
\hline & 3.950 & 0.1411 & 0.3500 \\
\hline & 5.702 & 0.3701 & 0.6437 \\
\hline & 7.750 & 0.6421 & 0.8366 \\
\hline & 8.817 & 0.7859 & 0.9095 \\
\hline & 9.082 & 0.8228 & 0.9265 \\
\hline & 9.857 & 0.9390 & 0.9760 \\
\hline \multirow[t]{7}{*}{210} & 6.220 & 0.0919 & 0.2203 \\
\hline & 7.100 & 0.1711 & 0.3603 \\
\hline & 9.409 & 0.3737 & 0.6070 \\
\hline & 12.257 & 0.6110 & 0.7925 \\
\hline & 14.269 & 0.7803 & 0.8918 \\
\hline & 15.013 & 0.8446 & $0.9254=$ \\
\hline & 16.350 & 0.9517 & 0.9777 \\
\hline \multirow[t]{7}{*}{250} & 11.353 & 0.0631 & 0.1312 \\
\hline & 13.400 & 0.1801 & 0.3233 \\
\hline & 16.856 & 0.3638 & 0.5418 \\
\hline & 21.274 & 0.5934 & 0.7388 \\
\hline & 25.160 & 0.7735 & 0.8620 \\
\hline & 26.366 & 0.8338 & 0.9002 \\
\hline & 28.758 & 0.9499 & 0.9705 \\
\hline \multirow[t]{7}{*}{280} & 17.352 & 0.0637 & 0.1127 \\
\hline & 19.200 & 0.1411 & 0.2308 \\
\hline & 24.700 & 0.3680 & 0.4995 \\
\hline & 31.459 & 0.6113 & 0.7145 \\
\hline & 37.200 & 0.7893 & 0.8467 \\
\hline & $39.000^{\circ}$ & 0.8433 & 0.8855 \\
\hline & $42.337^{-}$ & 0.9546 & 0.9666 \\
\hline
\end{tabular}


Table 2

Thermodynamic Data Analysis

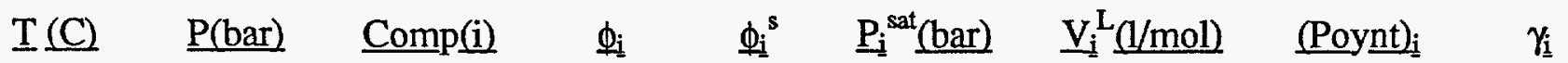
180

\begin{tabular}{|c|c|c|c|c|c|c|c|}
\hline \multirow[t]{2}{*}{3.452} & 1 & 0.9549 & 0.8539 & 10.2730 & 0.1134 & 0.9797 & 1.0846 \\
\hline & 2 & 0.9100 & 0.9248 & 2.8662 & 0.1473 & 1.0023 & 1.0000 \\
\hline \multirow[t]{2}{*}{3.950} & 1 & 0.9469 & 0.8539 & 10.2730 & 0.1134 & $0: 9811$ & 1.0780 \\
\hline & 2 & 0.8977 & 0.9248 & 2.8662 & 0.1473 & 1.0042 & 1.0081 \\
\hline \multirow[t]{2}{*}{5.702} & 1 & 0.9200 & 0.8539 & 10.2730 & 0.1134 & 0.9863 & 1.0545 \\
\hline & 2 & 0.8566 & 0.9248 & 2.8662 & 0.1473 & 1.0112 & 1.0307 \\
\hline \multirow[t]{2}{*}{7.750} & 1 & 0.8899 & 0.8539 & 10.2730 & 0.1134 & 0.9924 & 1.0322 \\
\hline & 2 & 0.8110 & 0.9248 & 2.8662 & 0.1473 & 1.0193 & 1.0620 \\
\hline \multirow[t]{2}{*}{8.817} & 1 & 0.8745 & 0.8539 & 10.2730 & 0.1134 & 0.9956 & 1.0218 \\
\hline & 2 & 0.7881 & 0.9248 & 2.8662 & 0.1473 & 1.0235 & 1.0825 \\
\hline \multirow[t]{2}{*}{9.082} & 1 & 0.8708 & 0.8539 & 10.2730 & 0.1134 & 0.9964 & 1.0188 \\
\hline & 2 & 0.7825 & 0.9248 & 2.8662 & 0.1473 & 1.0246 & 1.0853 \\
\hline \multirow[t]{2}{*}{9.857} & 1 & 0.8598 & 0.8539 & 10.2730 & 0.1134 & 0.9987 & 1.0054 \\
\hline & 2 & 0.7665 & 0.9248 & 2.8662 & 0.1473 & 1.0277 & 1.0912 \\
\hline \multirow[t]{2}{*}{6.220} & 1 & 0.9332 & 0.8019 & 16.8371 & 0.1219 & 0.9683 & 1.0643 \\
\hline & 2 & 0.8656 & 0.8872 & 5.1856 & 0.1551 & 1.0040 & 1.0007 \\
\hline \multirow[t]{2}{*}{7.100} & 1 & 0.9212 & 0.8019 & 16.8371 & 0.1219 & 0.9709 & 1.0506 \\
\hline & 2 & 0.8479 & 0.8872 & 5.1856 & 0.1551 & 1.0074 & 1.0024 \\
\hline \multirow[t]{2}{*}{9.409} & 1 & 0.8913 & 0.8019 & 16.8371 & 0.1219 & 0.9777 & 1.0320 \\
\hline & 2 & 0.8036 & 0.8872 & 5.1856 & 0.1551 & 1.0164 & 1.0146 \\
\hline \multirow[t]{2}{*}{12.257} & 1 & 0.8563 & 0.8019 & 16.8371 & 0.1219 & 0.9862 & 1.0224 \\
\hline & 2 & 0.7519 & 0.8872 & 5.1856 & 0.1551 & 1.0277 & 1.0397 \\
\hline \multirow[t]{2}{*}{14.269} & 1 & 0.8321 & 0.8019 & 16.8371 & 0.1219 & 0.9922 & 1.0130 \\
\hline & 2 & 0.7170 & 0.8872 & 5.1856 & 0.1551 & 1.0357 & 1.0574 \\
\hline
\end{tabular}

210

0.7170

0.8872

5.1856 
Table 2 (cont'd)

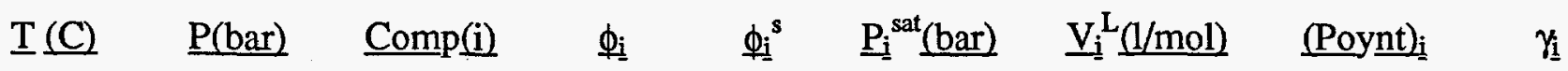

$\begin{array}{llllllll}15.013 & 1 & 0.8233 & 0.8019 & 16.8371 & 0.1219 & 0.9945 & 1.0086 \\ & 2 & 0.7045 & 0.8872 & 5.1856 & 0.1551 & 1.0387 & 1.0625 \\ & & & & & & & \\ 16.350 & 1 & 0.8076 & 0.8019 & 16.8371 & 0.1219 & 0.9985 & 1.0062 \\ & 2 & 0.6823 & 0.8872 & 5.1856 & 0.1551 & 1.0441 & 1.0722\end{array}$

250

11.353

1

0.9091

0.7250

29.8671

0.1397

$\begin{array}{ll}0.9423 & 1.0518\end{array}$

0.8066

$0.8254 \quad 10.2218$

0.1687

$1.0044 \quad 1.0021$

$13.400 \quad 1$
$\quad 2$

0.8863

0.7250

29.8671

0.1397

0.9485

1.0380

0.7743

$0.8254 \quad 10.2218$

0.1687

$1.0124 \quad 1.0026$

16.856

1
2

0.8503

0.7250

29.8671

0.1397

10.2218

0.1687

0.9591

1.0279

0.8254

0.8065

0.7250

29.8671

0.1397

10.2218

0.1687

1.0261

1.0134

$\begin{array}{ll}21.274 & 1 \\ & 2\end{array}$

25.160

1
2

0.7693

0.8254

10.2218

$\begin{array}{ll}0.7250 & 29.8671\end{array}$

0.1397

10.2218

0.1687

0.9728

1.0141

1.0438

1.0256

26.366

$\begin{array}{ll}1 & 0.7578 \\ 2 & 0.5938\end{array}$

$0.7250 \quad 29.8671$

0.1397

10.2218

0.1687

0.9850

1.0113

0.825

0.7353

0.7250
0.8254

29.8671

0.1397

10.2218

0.1687

1.0597

1.0441

28.758

$280 \quad 17.352$

1
2

0.8891
0.7520

0.6626

43.8472

0.1722

0.7718

15.9311

0.1831

0.9888

1.0646

1.0075

1.0466

19.200

$\begin{array}{ll}1 & 0.8716 \\ 2 & 0.7270\end{array}$

0.6626

43.8472

0.1722

15.9311

0.1831

0.9118

$0.9964 \quad 1.0013$

$1.0745 \quad 1.0545$

$\begin{array}{ll}24.700 & 1 \\ & 2\end{array}$

$\begin{array}{ll}1 & 0.8216 \\ 2 & 0.6575\end{array}$

0.6626
0.7718

43.8472
15.9311

0.1722

0.9308

$0.9056 \quad 1.0375$

$1.0057 \quad 1.0000$ 
Table 2 (cont'd)

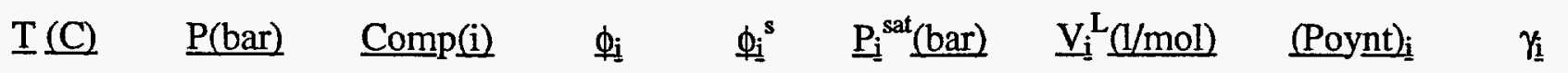

$\begin{array}{llllllll}31.459 & 1 & 0.7646 & 0.6626 & 43.8472 & 0.1722 & 0.9547 & 1.0135 \\ & 2 & 0.5775 & 0.7718 & 15.9311 & 0.1831 & 1.0638 & 1.0204 \\ 37.200 & 1 & 0.7179 & 0.6626 & 43.8472 & 0.1722 & 0.9754 & 1.0109 \\ & 2 & 0.5107 & 0.7718 & 15.9311 & 0.1831 & 1.0884 & 1.0329 \\ & & & & & & & \\ 39.000 & 1 & 0.7032 & 0.6626 & 43.8472 & 0.1722 & 0.9820 & 1.0092 \\ & 2 & 0.4900 & 0.7718 & 15.9311 & 0.1831 & 1.0962 & 1.0359 \\ & & & & & & & \\ 42.337 & 1 & 0.6752 & 0.6626 & 43.8472 & 0.1722 & 0.9944 & 1.0018 \\ & 2 & 0.4562 & 0.7718 & 15.9311 & 0.1831 & 1.1109 & 1.0404\end{array}$




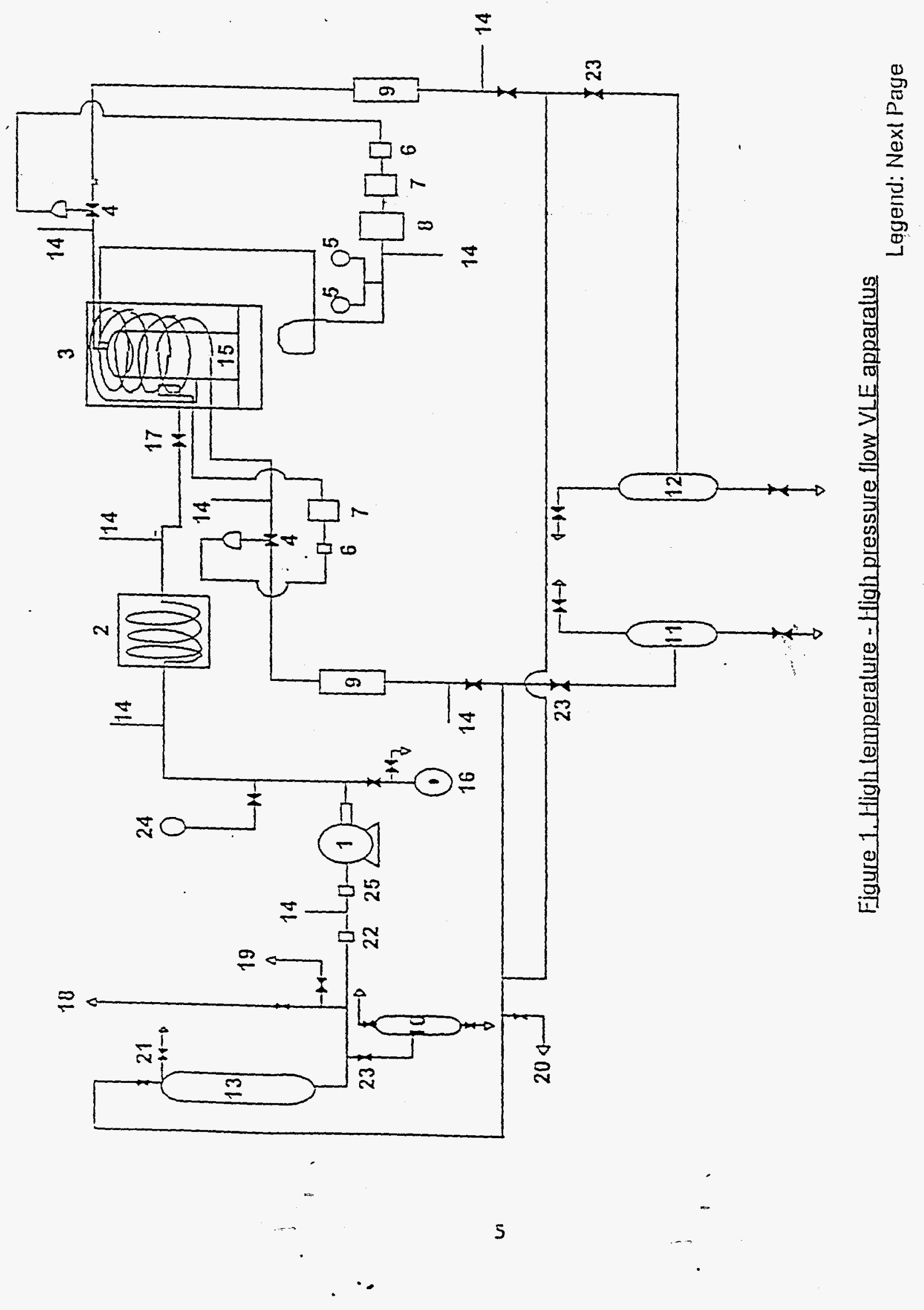


1. Positive displacement feed pump

2. Preheater oven

3. Main oven

4. Level and pressure control valves

5. Pressure gages

2. Electric to pneumatic transducer for liquid level and pressure control loops

7. Pressure and liquid level controllers

8. Pressure transmitter

9. Heat exchangers for liquid and vapor

10. Feed sample collector

11. Liquid sample collector

12. Vapor sample collector

13. Feed tank

14. Thermocouples

15. Vapor-liquid equilibrium cell

10. Pressure relief saiety valve/rupture disk

17. High temperature hand control valve

18. Feed fill line

19. Pressure test gas inlet

20. Drain point

21. Vent point

22. $60 \mu \mathrm{m}$ Strainer

23. Needle valves

24. Pump discharge pressure gage

25. 230 um Strainer 


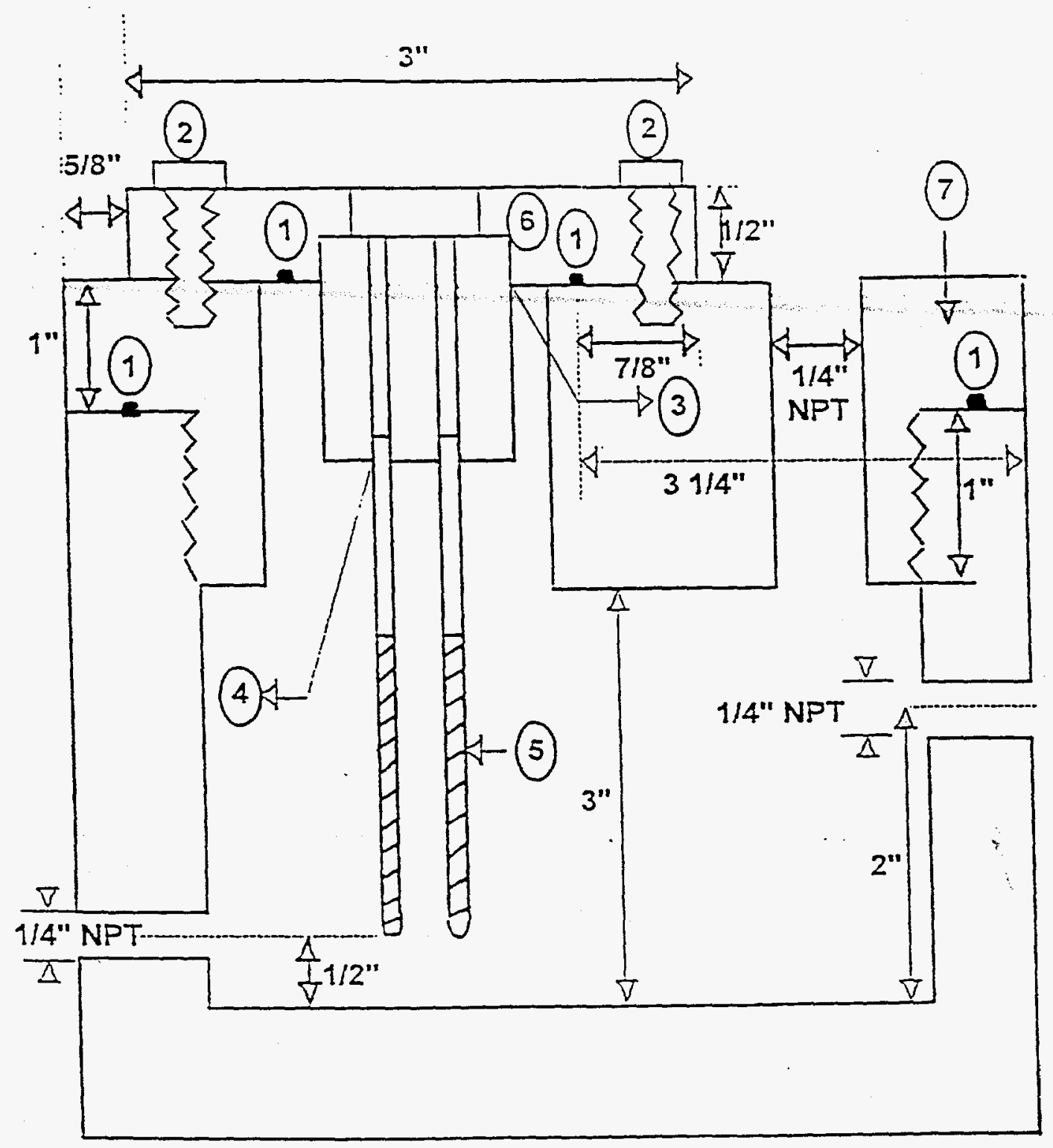

Fiqure 2. Equilibrium cell for the VLE apparatus

Legend:
1. O-ring
2. $3 / 16^{\prime \prime} \times 7 / 8^{\prime \prime}$ bolts
5. 316 SS tubes with sensors for level measurement
3. Small iillet weld
6. Flange for liquid level sensor
4. Trepan and weld
7. Lid of VLE cell

Note: The cell is made of SS 315 and has a wall thickness of $1 "$ all through. 


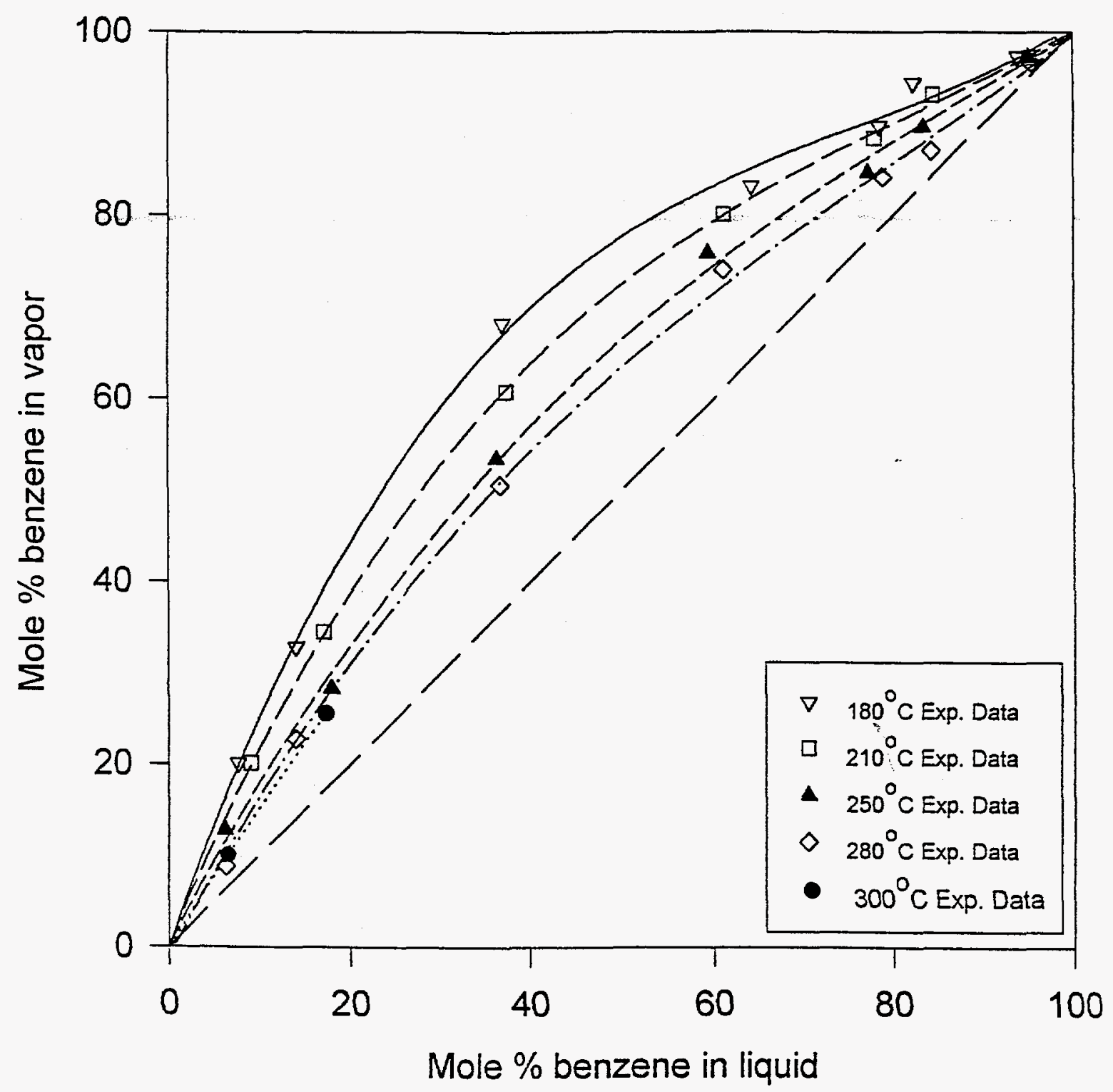

Figure 3: : xy-diagram for all measured data (symbols represent experimental data and solid lines represent regressed carves). 


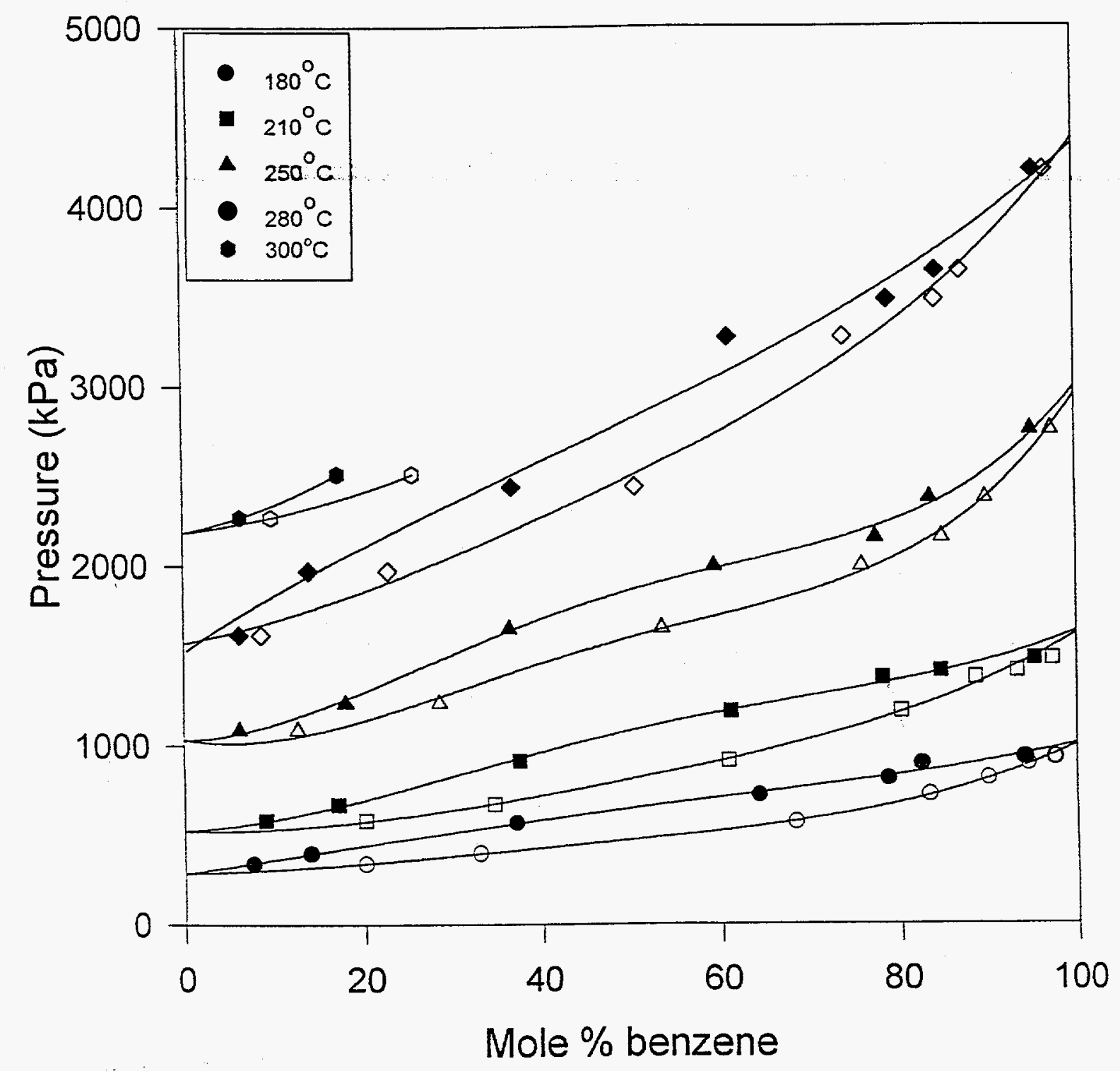

Figure 4: $\quad$-xy diagram for all measured data (symbols represent experimental data and solid lines represent regressed carves). 


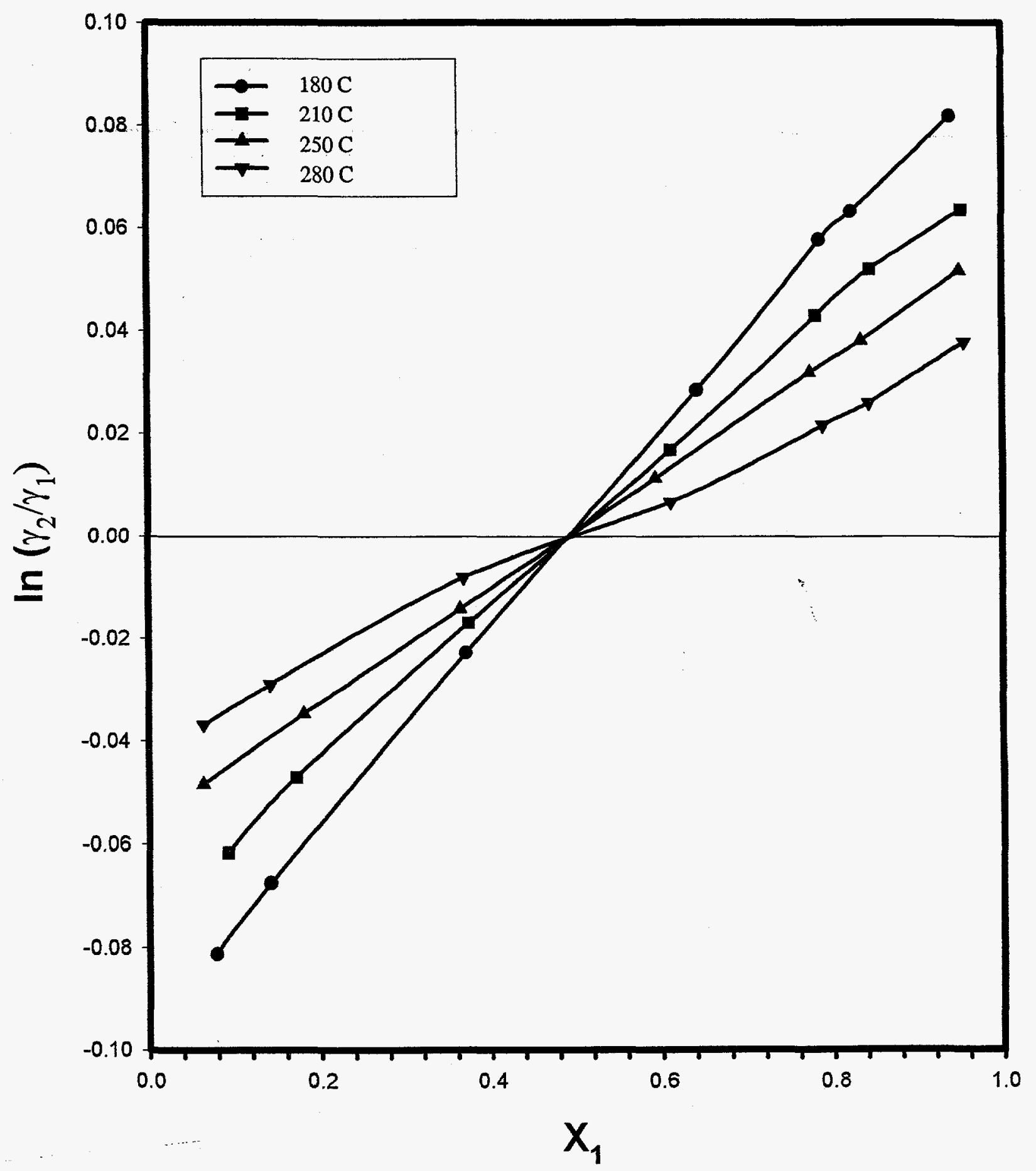

Figure 5: This figure illustrates the thermodynamic consistency of the measured data as discussed in the text. 